Animal Health Research Institute, Assiut Lab.

\title{
PATHOLOGICAL AFFECTIONS ASSOCIATED WITH STAPHYLOCOCCUS AUREUS INFECTION IN SOME RABBIT'S FARMS IN ASSIUT GOVERNORATE
}

(With 2 Tables and 12 Figures)

\section{By}

\section{NEVEEN A. EL NISR and AZHAR M. HASSAN}

(Received at 15/1/2011)

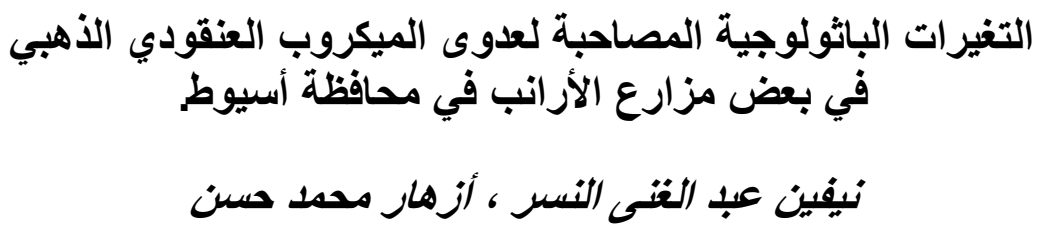

أجريت هذه الدراسة علي عدد 135 من الأر انب التي تتر اوح أعمار ها بين شهر إلى ثلاث شهور

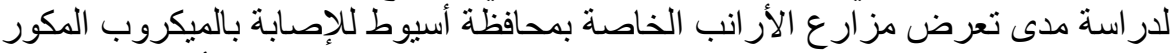

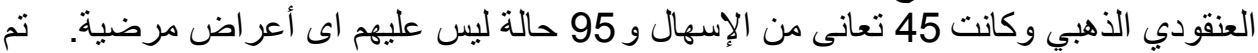

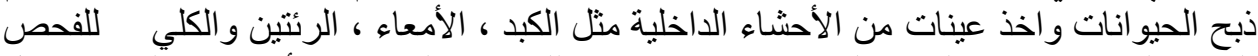

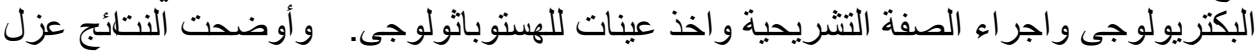
الميكروب المكور العنقودي الذهبي من 33 حالة بنسبة

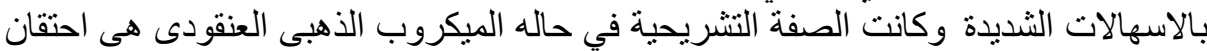

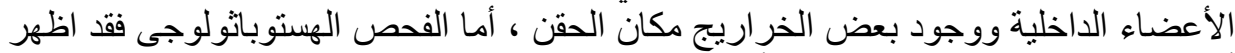

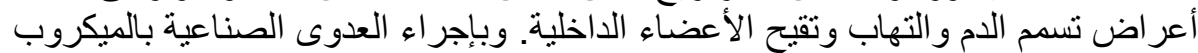

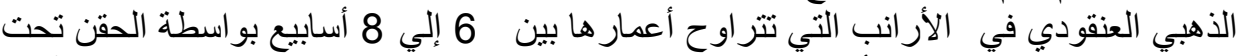

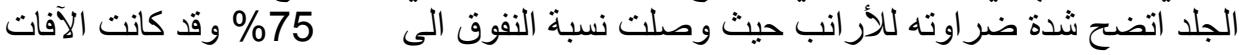
التشريحية تشبه إلى حد كبير تلأك التي سجلت في العدوى الطبيعية.

\section{SUMMARY}

A Total 135, 1-3 months aged rabbits were used for this study. Faecal swabs were aseptically collected from different rabbit farms in Assiut Governorate. Diarrhea, ruffled fur and depression were observed in 45 out of them, while the rest were apparently healthy and 8 rabbits were chosen to be the control. These samples were examined bacteriologically for determination of the occurrence and frequency of Staph. aureus. Thirty three isolates from the diseased rabbits at percentage of $(24.4 \%)$ were positive for Staph. aureus. Experimental infection in 6-8 week-old rabbits 
via subcutaneous (S/C) injection of isolated Staph. aureus led to $75 \%$ mortality with post-mortem lesions similar to a great extent to those of natural infection. Reisolation of infecting organism from internal organs and intestinal tract of dead and slaughtered rabbits at the end of observation period were conducted. Histopathological examination of the affected tissue revealed signs of septicemia and suppuration in various organs.

Key words: Staphylococcus aureus, rabbits, pathology.

\section{INTRODUCATION}

Staphylococcus aureus is a bacterium, frequently living on the skin or in the nose of a healthy rabbits, that can cause illnesses ranging from minor skin infections (such as pimples, boils, and cellulitis) and abscesses, to life-threatening diseases such as pneumonia, meningitis, endocarditis and septicemia (Renquist and Soave, 2001). Staphylococcosis is a commonly occurring disease resulting in a fatal generalized septicemia or localized suppurative inflammation in both domestic and wild rabbits (Flatt, 1974). The disease is usually sporadic and of little economic importance for commercial rabbits. Most often, suppurative lesions with staphylococcal infection, often lead to chronic abscessation in affected sites. The acute septicemic form occurs mostly in neonatal kits and can have few and nonspecific lesions or multifocal and suppurative ones in various organs, including the lungs, kidneys, spleen, heart and liver (Percy and Barthhold 2001). Ajuwape and Aregbesola (2002) isolated Staph.aureus from upper respiratory tract of healthy rabbits with an incidence of $100 \%$. Staph. aureus is frequently associated with bacterial conjunctivitis and keratitis in rabbits. Staph. aureus is catalase-positive and able to convert hydrogen peroxide to water and oxygen. This makes the catalase test useful to distinguish staphylococci from enterococci and streptococci. A small percentage of Staph. aureus can be differentiated from most other staphylococci by the coagulase test as Staph. aureus is primarily coagulase-positive that causes clot formation, whereas most other staphylococcal species are coagulase-negative. (Vasquez and Lowy, 2007). In spite of the majority of Staph. aureus are coagulase-positive, some may be atypical in that they do not produce coagulase. The most common organism in patients with nosocomial bacteremia is coagulasenegative staphylococcus, (Standland et al., 2008). Incorrect identification of an isolate can impact implementation of effective treatment and/or control measures. To the avaliable of our knowledge, there is no complete 
data about the problem of rabbit staphylococcosis in Egypt, in spite of its importance as a common disease in rabbit farms. Therefore the present work was designed to isolate and identify Staph. aureus from apparently healthy and diseased rabbits in Assiut Governorate followed by experimental infection using the isolated organism in 6-8 weeks old rabbits by subcutaneous route.

\section{MATERIALS and METHODS}

\section{1- Collection of samples:}

Fecal swabs were collected aseptically from 135 rabbits from different farms in Assiut Governorate for investigating the occurrence and pathogenicity of the Staph. aureus. Out of them, 45 samples were from diarrhic rabbits and 8 from apparently healthy rabbits were positive.

\section{2- Bacteriological examination:}

\section{a- Samples:}

Tissue samples from liver, heart, lungs, kidneys, as well as samples from suppurative lesions were collected and subjected to bacteriological examination.

\section{b- Media:}

Sodium chloride broth, Pepton water, nutrient broth, glucose phosphate broth, semi-solid agar and sugars (glucose, lactose, lactose, maltose, sucrose, galactose and xylose) Barid-parker agar, blood agar, nutrient agar, simmon, s citrate agar, and triple sugar iron agar and urea agar Kovac's, urea, methyl red, oxidase, andrade, s indicator, rabbit sera and Gram, s stain.

\section{C- Isolation and Identification of staph. strains:}

Samples from individual rabbits including liver, lungs, kidneys, and pus were collected aseptically. Lopopfull from these samples were inoculated into sodium chloride broth and incubated at $37{ }^{\circ} \mathrm{C}$ for $18-24$ hour, followed by sub-culturing on solid media as: Baried-parker agar media at $37{ }^{\circ} \mathrm{C}$ for $48 \mathrm{~h}$ as a selective medium for staphylococci (Bairdparker, 1962), Blood agar and nutrient agar media at $37 \mathrm{c}^{\circ} \mathrm{C}$ for $24 \mathrm{~h}$. The obtained colonies were picked up and stored in semisolid agar for further identification, morphologically, microscopically and biochemically according to Cruckshank et al. (1975); Baird-parker (1979).

\section{3- Pathogencity test:}


Thirteen 4- 8 week-old Balady rabbits obtained from private farms in Assiut Governorate were used. The animals were kept in cages under observation for one week. A random sample of 3 rabbits was slaughtered and exposed to post-mortem and parasitological examinations for coccidia and other parasitic infestations and bacteriological examination for Staph. aureus and other pathogenic bacteria, which proved their healthy status and free from diseases. The others were classified into 2 groups: Group one of (7) rabbits were inoculated subcutaneouly with $0.5 \mathrm{ml}$ of $24 \mathrm{~h}$. broth culture (30x1010 viable organism/ rabbit) while Group two (3) rabbits were kept without inoculation as non-infected control. All animals were kept for 20 days (period of observation) with daily examination for clinical signs, number of dead rabbits and gross P.M. lesions in dead and scarified animals till the end of the observation period as well as trials of reisolation were conducted.

\section{3- Reisolation of infecting organism.}

\section{4-Tissue sampling:}

After slaughtering of the diseased rabbits, samples were taken from the intestines for bacteriological examination. For pathological examination, specimens from the intestines, liver, kidneys and lungs were taken, fixed in $10 \%$ neutral buffered formalin and processed as usual. Serial sections of $4 \mu \mathrm{m}$ thickness were obtained and stained with hematoxylin and eosin (H and E) according to Bancroft et al. (1996).

\section{RESULTS}

Isolation and identification of Staph. aureus revealed a grampositive coccus, in grape-like clusters when viewed through a microscope. More characteristic is its appearance when grown out on agar plates. It appears as large, round golden-yellow (a feature from which the name come) colonies, with beta-haemolysis of blood agar (Fig 1a,b).According to morphological and bio-chemical characters, 33 isolates $(24.40 \%)$ were identified to be Staph. aureus (Table 1 and Fig 2). These isolates were Gram positive cocci usually arranged in clusters and characterized by its typical growth of coagulase positive, black colonies surrounded by faint yellow zone on Baird-Parker agar media and its haemolytic activity on blood agar media.

Table 1: Frequency percentage of Staph. aureus isolates. 


\begin{tabular}{|c|c|c|}
\hline $\begin{array}{c}\text { General status of } \\
\text { isolated rabbit }\end{array}$ & No. of examined rabbits & Staph. aureus isolates \\
\hline Apparently healthy & 8 (out of 90) & $1.20 \%$ \\
\hline Diseased & 33 (out of 45) & $24.40 \%$ \\
\hline Total & 135 & \\
\hline
\end{tabular}

\section{Fig (2)The frequency of staphylococus aureus infection}

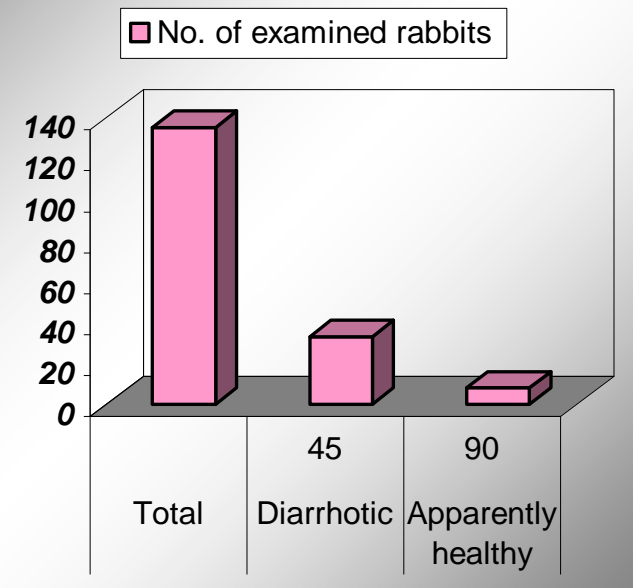

\section{2- Experimental infection in rabbits}

Results of pathogenicity tract are given in Table (2) and Fig. (3)

Table 2: Showing results of pathogenicity test

\begin{tabular}{|c|c|l|l|l|}
\hline $\begin{array}{l}\text { Total No. of } \\
\text { rabbits used for } \\
\text { pathogenicity } \\
\text { test }\end{array}$ & $\begin{array}{l}\text { Rabbits used for } \\
\text { preliminary } \\
\text { investigation }\end{array}$ & $\begin{array}{l}\text { No. of } \\
\text { inoculated } \\
\text { rabbits }\end{array}$ & $\begin{array}{l}\text { No. of control } \\
\text { rabbits }\end{array}$ & $\begin{array}{l}\text { Rabbits died } \\
\text { during } \\
\text { observation } \\
\text { period }\end{array}$ \\
\hline 13 & 3 & 7 & 3 & 4 \\
\hline
\end{tabular}

\section{A- Clinical signs:}


Majority of the rabbits inoculated with Staph. areus appeared suffering from loss of appetite, ruffled fur and depression. Diarrhea and subcutaneous abscesses at the site of inoculation were observed in some cases. In the late stages, sick animals showed emaciation followed by death. The Staph. aureus. was reisolated from the internal organs and suppurative tissues of dead and scarified rabbits.

\section{B- Gross pathology}

Group of rabbits inoculated with Staph. areus showed congestion of the internal organs (liver, lungs, intestines, spleen and kidneys) and several minute focal pus nodules (abscessation) in the internal organs. Pneumonia and catarrhal enteritis were observed in most of the examined cases (Figs. 4a,b). No symptoms were observed in the control group. The number of dead rabbits are given in Table (2).

\section{C- Histopatholoy:}

The liver showed varying degrees of vacuolar degeneration and necrotic changes the degenerated hepatocytes showed cytoplasmolysis and weakly stained nuclei (Fig. 5). The necrotic hepatocytes showed acidophilic coagulated cytoplasm and in between the necrotic cells a few heterophil and macrophage cells infiltrations were observed (Fig. 6). Portal blood vessels and central veins were sometimes thrombosed and surrounded with few leucocytic infiltrations (Figs. 7,8). The epithelium of the bile ductules were necrosed and desquamated and they were surrounded with edema and leucocytic infiltrations (Fig. 9). The bronchial and alveolar epithelial cells were necrosed with leucocytic infiltration, and some of the blood vessels were thrombosed (Figs. 10, 11). The intestines showed increased numbers of the goblet cells and the epithelium showed degenerative and necrotic changes, The lamina propria was hyperemic, edematous and showed leukocytic cellular infiltrations (Fig 12). Examination of the kidneys revealed that the tubular epithelium and the glomerular tuffet showing necrobiotic changes with few leucocytic infiltrations (Fig. 13). 
Assiut Vet. Med. J. Vol. 57 No. 129 April 2011
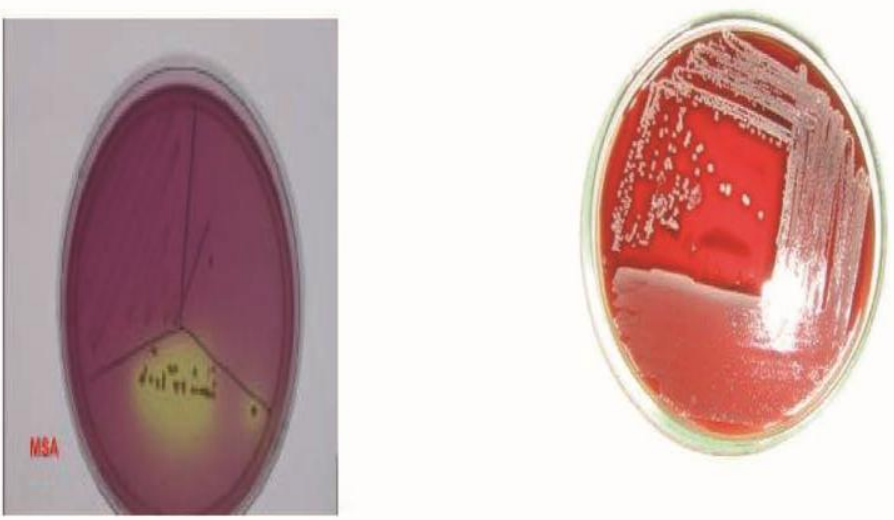

$1-B$

$1-\mathrm{A}$ 
Assiut Vet. Med. J. Vol. 57 No. 129 April 2011
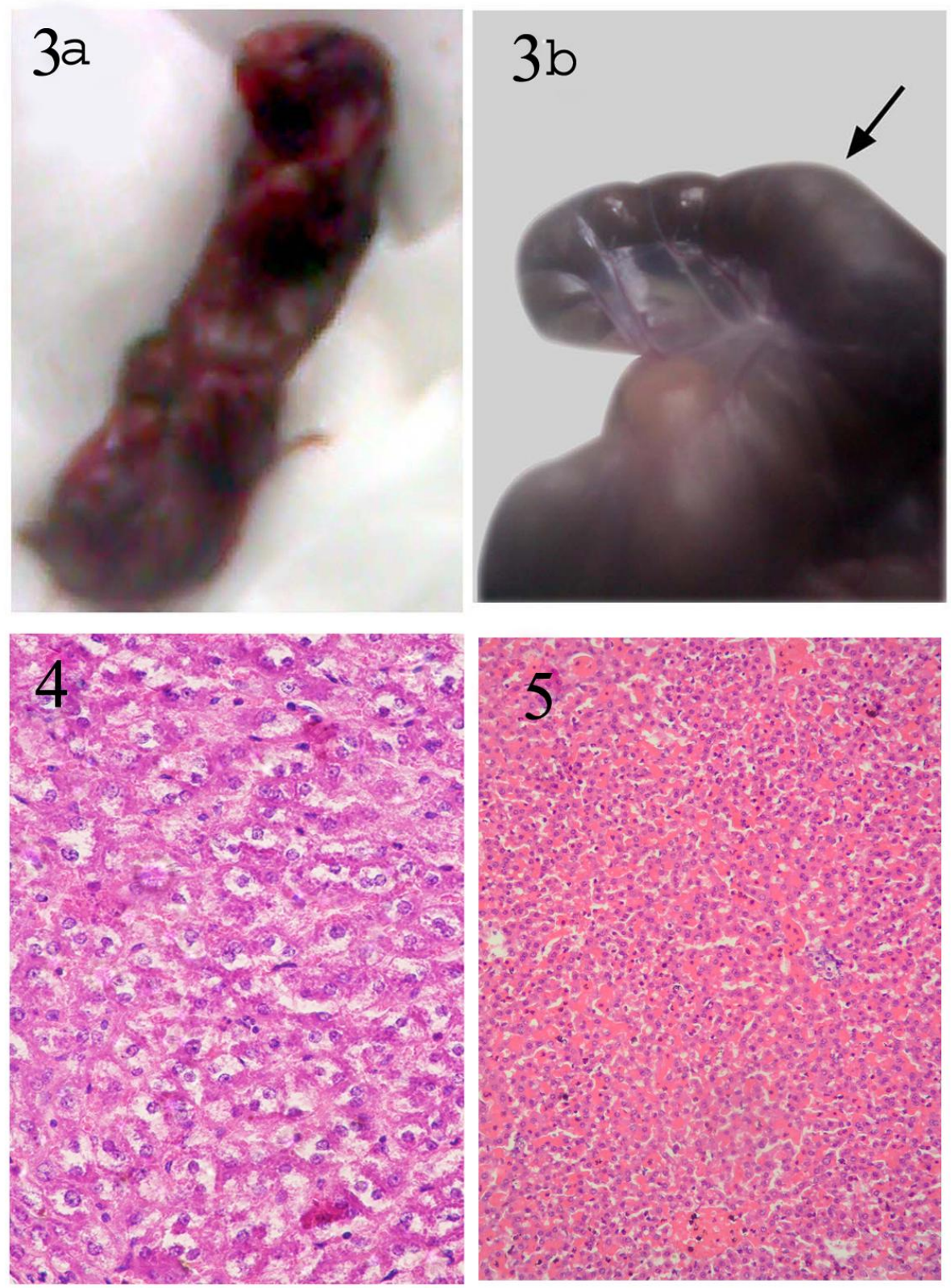
Assiut Vet. Med. J. Vol. 57 No. 129 April 2011
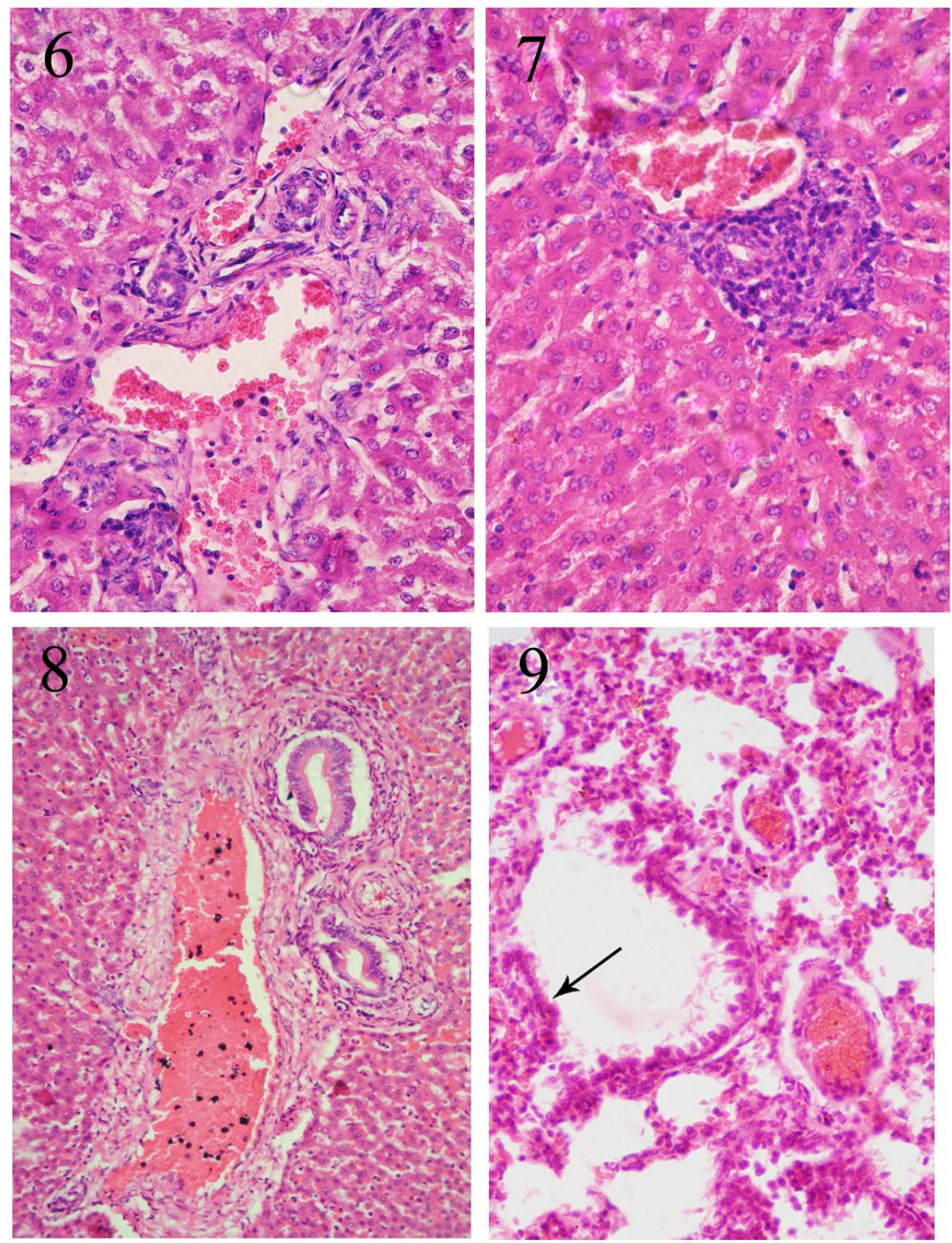

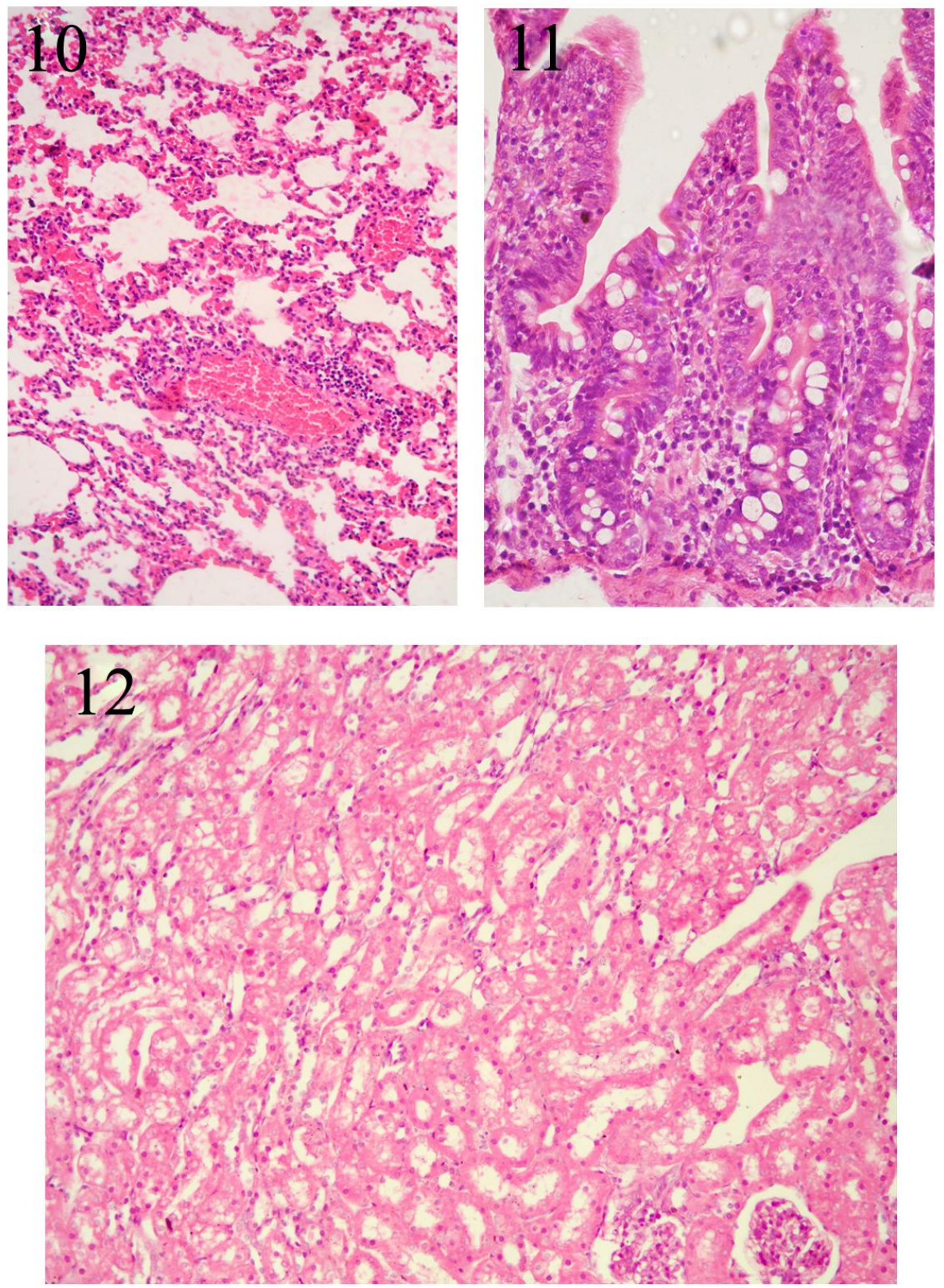


\section{LEGEND OF FIGURE}

Fig. (1a,b): Yellow colonies of Staph. aureus on a blood agar plate. Note regions of clearing around colonies caused by lysis of red cells in the agar (beta haemolysis).

Fig. (3 a): Showing sever congestion of the intestine of diseased rabbits.

Fig. (3 b): Showing intestine of diseased rabbits filled with fluid and gases.

Fig. (4a): Showing sever congestion of the intestine of diseased rabbits

Fig.(4b): Showing intestine of diseased rabbits filled with fluid and gases.

Fig. (5): Liver of infected rabbits with staph. aureus showing vacuolar degeneration and cytoplasmolysis X25.

Fig. (6): Liver of infected rabbits with Staph. aureus showing leukocytic infiltration between necrosed hepatic cells . X10.

Fig. (7): Liver of infected rabbits with Staph. aureus showing congestion of the portal blood vessels which surrounded with leukocytic infiltration X25.

Fig. (8): Liver of infected rabbits with Staph. aureus showing thrombus in the central vein which surrounded with leukocytic infiltration X25.

Fig. (9): Liver of infected rabbits with Staph. aureus showing thrombus in the portal vein and the portal area surrounded with degenerated hepatic cells and cellular infiltration. X 25 .

Fig.(10): Lung of infected rabbits with Staph. aureus showing thrombus in the pulmonary blood vessels and necrosis of the bronchiolar epithelium (arrow) X10.

Fig. (11): Lung of infected rabbits with Staph. aureus showing leukocytic infiltration in the alveolar wall with congestion in the pulmonary blood vessels X10.

Fig. (12): Intestine of infected rabbits with Staph. aureus showing increased number of goblet cell and inflammatory cell infiltration in the lamina propria. X25.

\section{DISCUSSION}

The fact that Staph. aureus had been isolated from 33 of 45 diseased rabbits and only from 8 out of 90 apparently healthy rabbits was supported by the concept that the bacterial population in a rabbit's intestinal tract are considered with most delicately balanced of any all herbivorous mammals. The growth and activity of normal (favorable) bacteria tend to check the potentially harmful bacteria (Fennested, 1985; 
Digiacomo and Thouless, 1984). It has been postulated that Staph. aureus have an ability to escape and influence the host immune system (AbdelGwad et al., 2004), hence it's over growth and multiplication result in the production of toxins that are rapidly absorbed into the rabbit's circulation quickly causing illness and death (hence the higher of Staph. aureus isolation from diseased rabbits 67\%) As evident from our results, the bacteriological examination of the specimens revealed that Staph. aureus was recovered from $24.40 \%$ of the examined rabbits. A nearly similar finding was mentioned by Ali (1991) 23.1\%. A lower percentage was reported by Abd-EL-Motelib and Salem (1991) who isolated six strains of B. hemolytic coagulate positive Staph. aureus from infecting lactating does and their suckling rabbits. A much higher percentage was described by Ajuwape and Aregbesola (2002) who isolated Staph. aureus from upper respiratory tract of health rabbits with an incidence of $100 \%$. In our experiment a nearly 56\% mortality was reported however Abd-EL-Motelib and Salem (1991) found that Staph.aureus caused 100\% mortality in experimentally infected rabbits with the same dose and route of inoculation. Reisolation of the organism from dead and scarified slaughtered animals were conducted and this proved that the inoculated isolates were responsible for pathogenic affect mentioned before.

Our clinical signs i.e. anorexia, depression and death are similar to those observes by Abdel-Gwad et al. (2004); Camguilhem and Milon (1989). Harkness and Wagner (1983) suggested that the sudden death of animals was due to pneumonia and the septicemia. Pneumonia, focal area of purrulent inflammation and septicemia were detected grossly in rabbits used for these investigation. Our results were in complete harmony with those recorded by Michael and Ekhaus (1997); Richard (1997); Percy and Barthhold (2001); Dalia et al. (2003); while Alp et al. (2004) stated that sepsis appeared as a result of Staph. areus infection of the lung, liver and spleen macroscopically but their histopathological investigation revealed only inflammation. Necrotizing lesions were observed in the liver and kidneys with moderate amount of leucocytic infiltration consists mainly of neutrophil cells. Such lesions were also reported by Quensenbery (1997); Percy and Barthold (2001) who postulated that the necrotizing lesions was due to the fact that Staph. aureus produce lethal toxins for rabbit's heterophils, protein A which binds fe portion of $\operatorname{IgG}$ thus the bactericidal mechanism of the host are blocked. Focal areas of bronchopneumonia with congestion and thrombosis of the pulmonary vasculature were good evidence of infection and toxemia. Pneumonic areas were reported also by Coord and Yoneda (1981); Cohen (1991). Catarral entritis were reported in 
the intestine of all examined rabbits these due to the fact that Staph. aureus have peptidoglycen in it's cell wall which leads to strong ability of modifying the function of some immune cells Bai Sui et al. (2007).

From these studies it had been concluded that Staph. aureus were isolated from diarrheic rabbits (33 out of 45 rabbits) and from apparently health rabbits ( 8 out of 90 rabbits). The isolates were identified morphologically and biochemically. Experimental inoculation of isolates in rabbits results in necrotizing inflammatory lesions in the liver, kidneys, lungs and intestine, indicating that the isolates were pathogenic for rabbits.

\section{REFERENCES}

Ali, H.A. (1991): The problem of bacterial respiratory diseases in rabbit. M.V.Sc. of Vet. Med. Assiut Univ.

Abdel-Gwad, A.M.; Abdel-Rahman, A.A. and Ali, M.M. (2004): Significance of Staph. aureus in rabbits in Assiut governorate. Ass. Univ. Bull. Environ. Res. Vol. 7 No. 1 March 2004.

Abdel-Motelib, T.Y. and Salem, B. (1991): Staphylococcal mastitis in Domestic rabbits. Assiut Vet. Med. J. Vol. 25, No.49, Aprial.

Ajuwape, T.P. and Aregbesola, E.A. (2002): The bacterial flora of the upper respiratory tract of normal rabbits. Israel Vet. Med. Assoc. Vol. 57 (2) 2 .

Alp, E.; Gozukucuk, S.; Canoz, O.; Kirmaci, B. and Doganay, M. (2004): Effect of granulocyte colony-stimulating factor in experimental methicillin resistant Staph. aureus sepsis. BMC Infect. Dis., 4:43

Bai-Sui Feng; Shao-Heng Peng-yuan He.; Zheng, Lind Wu and PingChang Yang (2007): Mast cells play a crucial role in Staph. aureus peptidoglycan induced diarrhea. Am. J. Pathol. 171: 537-547.

Baird-parker, A.C. (1962): An improved diagnostic and selective medium for isolating coagulase positive staphylococci. J. Appl. Bact. 25:12.

Baird-parker, A.C. (1979): Methods for identifying staphylococci and micrococci. Identification methods for microbiologist 2 nd ed. Skinner, F. and Love Lock, D., PP. 201-209, London and New York, Academic Press.

Bancroft, J.D.; Stevens, A. and Turner, D.R. (1996): Theory and practice of histological techniques. $4^{\text {th }}$ Ed Churchill living stone, New York Edinburgh. Madrid, Sanfrancisco, Tokyo. 
Camguilhem, R. and Milon (1989): Biotypes and Oserogroup of Escherichia coli involved in intestinal infections of weaned rabbits: Clues to diagnosis of pathogenic strains. J. Clinc. Microbial. 27: 743-747.

Coorod, J.D. and Yoneda, K. (1982): Comparative role of complement in pneumococcal and staphylococcal pneumonia. Infect. Immun. 37(3): 1270-1277.

Cruckshank, R.; Duguid, L.; Marmian, B. and Swain, R. (1975): Medical Microbiology. 12 $2^{\text {th }}$ Ed. Vol. 11 EXS. Livingstone. Limited Edinburgh. London and New York.

Cohen, J.O. (1991): Staphy;ococcus. In Barons, ed., Medical Microbiology. New York, Chuchill Livingstone, pp. 203-214.

Dalia, O. Girgis; Joseph J. Dajcs and Richard J.O. Callaghan (2003):

Phospholipase A2 activity in normal and staphylococcus infected rabbit eyes. Investigative ophthalmology Visual Science, 44: 197-202.

Deveries, L.A. (1996): A new pathogenic Staph. aureus type in commercial rabbits. Zen. Tralbl. Vet. Med. 43: 313-15.

Digiacomo, R.F. and Thouless, M.E. (1984): Aged- related antibodies to Rota virus in New Zealand rabbit. J. Clin. Microbial. 19: 710-711.

Flatt, R.E. (1974): The biology of the laboratory rabbit. Eds. Weisbroth, H.Flatt, R.E. and Kraus, NewYork. Academic Press. P, 227.

Fennestad, K.L. (1985): Pathogenetic observations on pleural effusion disease in rabbits. Arch. Virol. 84: 163-174.

Goorod, J.D. and Yoneda, K. (1982): Comparative role of complement in pneumococcal and staphylococcal pneumonia. Infect. Immun. 37(3): 1270-1277.

Harkness, J.E. and Wagner, J.E. (1983): The biology and medicine of rabbits and rodents. $2^{\text {nd }}$ Ed. Lea and Febiger. Washington square, Philadelphia. pp. 169-171.

Hiller, E.V. and Quesenberry, K.E. (1997): Ferrets, Rabbits and Rodent clinical medicine and surgery. W.B Saunder company. A division of Harcourt Brace and company, Philadelphia pp. 198-200

Percy, D.H. and Barthold, S.W. (2001): Pathology of laboratory rodents and rabbits. $2^{\text {nd }}$ Ed library of congress cataloging in publication data pp: $260-280$.

Michael, A. and Eckaus (1997): Infection of the uterus with staphylococcus aureus. Results AFID Wednesday Slide Conference No. 10-3 December. 
Renquist, D. and Soave, O. (2001): Staphylococcal pneumonia in laboratory rabbit: Cited by Israel Vet. Med. Vol. 56 (2).

Richard, M. (1997): Results AFIP Wednesday Slide Conference. No. 1315 January. Diplomat, ACVP Department of pathology National Zoological Park Washington, D.C. 2008.

Standland, M.; Zhu, J. and Lu, C. (2008): "Single mutation on the surface of Staphylococcus aureus Sortase A can disrupt its dimerization". Biochemistry 47(6): 1667-74.

Percy, D.H. and Barthold, S.W. (2001): Pathology of laboratory rodents and rabbits. 2nd Ed library of congress cataloging in publication data pp: $260-280$.

Vasquez, G. and Lowy, F. (2007): "Heterosexua transmission of community-associated methicillin-resistant Staphylococcus aureus". Clin. Infect. Dis., 44 (3): 410-314. 